\title{
The prevalence and phenotype in Brazilian patients with inflammatory bowel disease
}

\author{
Adalberta Lima Martins ${ }^{1,4^{*}}$, Rhaisa Almeida Volpato ${ }^{2}$ and Maria da Penha Zago-Gomes ${ }^{3}$
}

\begin{abstract}
Background: The epidemiology of inflammatory bowel disease (IBD) varies in different countries. This study aimed to assess phenotype, medications, prevalence and incidence of IBD in the State of Espírito Santo, Brazil.

Methods: Patients with IBD who utilized the Public Medication-Dispensing System of the Department of Health of Espírito Santo, between August 2012 and July 2014. Of 1484 active patients, 1048 were analyzed, which included patients of all ages.

Results: The prevalence of IBD was 38.2 per 100,000 inhabitants, with ulcerative colitis (UC) being 24.1 per 100,000 and Crohn's disease (CD), 14.1 per 100,000. The incidence of IBD was 7.7 per 100,000 inhabitants/year (UC - 5.3/100,000 inhabitants/year and CD - 2.4/100,000 inhabitants/year). Out of the 1048 patients analyzed, 669 had UC (63.84\%), 357 had CD (34.06\%), and 22 had unclassified inflammatory bowel disease (UIBD; 2.10\%). There were 48/1048 (4.5\%) pediatric patients (16 years of age or younger). On the UC phenotype $(n=654)$, we observed left-sided colitis in 247 (37.7\%), pancolitis in 209 (31.9\%), and proctitis in 198 patients (30.2\%). Pancolitis was more frequent in pediatric patients $(p=0.007)$. CD showed a homogeneous distribution between ileitis (L1), colitis (L2), and ileocolitis (L3). Regarding the CD behavior ( $n=352$ ) observed the inflammatory type (B1) in $176(50 \%)$; fistulizing (B3) in 75 (21.2\%), isolated type (B3) in 29 (8.2\%), and perianal fistulizing type (B3p) in 46 (13.1\%). Biologic therapies were used in 154/357 (43.3\%).
\end{abstract}

Conclusion: The prevalence of the IBD in the state of Espírito Santo, Brazil was higher than in two other brazilian studies. There was high utilization of biologic therapies in patients with CD.

Keywords: Prevalence, Inflammatory bowel disease, Phenotype, Ulcerative colitis, Crohn's disease, Brazil

\section{Background}

Inflammatory bowel diseases (IBD) are complex processes [1] and are associated with regional epidemiological [2-5] and phenotypical [6-8] variations. Latin America, particularly Brazil, is considered to be a region with low prevalence and incidence of IBD, though there has been an increase in incidence in Brazil $[9,10]$. In 2015, Parent et al. found a prevalence of 12.8 cases/ 100,000 inhabitants in the northeast of Brazil [11].

According to the medication-dispensing protocol of the Ministry of Health, treatment for IBD in Brazil is provided by the federal government for all patients, including those from both the public and private systems [12-14].

Espírito Santo is a state located in the Southeast region of Brazil (Fig. 1). It has a large immigrant population of Italians and Germans [15], and in 2014, the population was $3,885,049$ [16].

The purpose of this study is to evaluate the prevalence, incidence, phenotype, and medications used in patients who received treatment for IBD through the dispensing pharmacies in the State of Espírito Santo.

\section{Methods \\ Ethical considerations}

This study had used secondary data from documentation required by the Ministry of Health in order to have access to highly expensive medication. As the

\footnotetext{
*Correspondence: adalbertalima@gmail.com; limambeta@uol.com.br ${ }^{1}$ State Management of Pharmaceutical Assistance and Ambulatory of Inflammatory Bowel Disease of the Health Department of Espírito Santo,
Núcleo Regional de Especialidades de Vitória, BR 262, Km 0, Ed. Eng. Cristiano Tavares, $2^{\circ}$ andar, Jardim América, Cariacica, Espírito Santo 29140-126, Brazil ${ }^{4}$ Desembargador Ferreira Coelho 330/315 Praia do Suá, Ed. Eldorado, Vitoria 29052210, Brazil

Full list of author information is available at the end of the article
}

(C) The Author(s). 2018 Open Access This article is distributed under the terms of the Creative Commons Attribution 4.0 International License (http://creativecommons.org/licenses/by/4.0/), which permits unrestricted use, distribution, and reproduction in any medium, provided you give appropriate credit to the original author(s) and the source, provide a link to the Creative Commons license, and indicate if changes were made. The Creative Commons Public Domain Dedication waiver (http://creativecommons.org/publicdomain/zero/1.0/) applies to the data made available in this article, unless otherwise stated. 


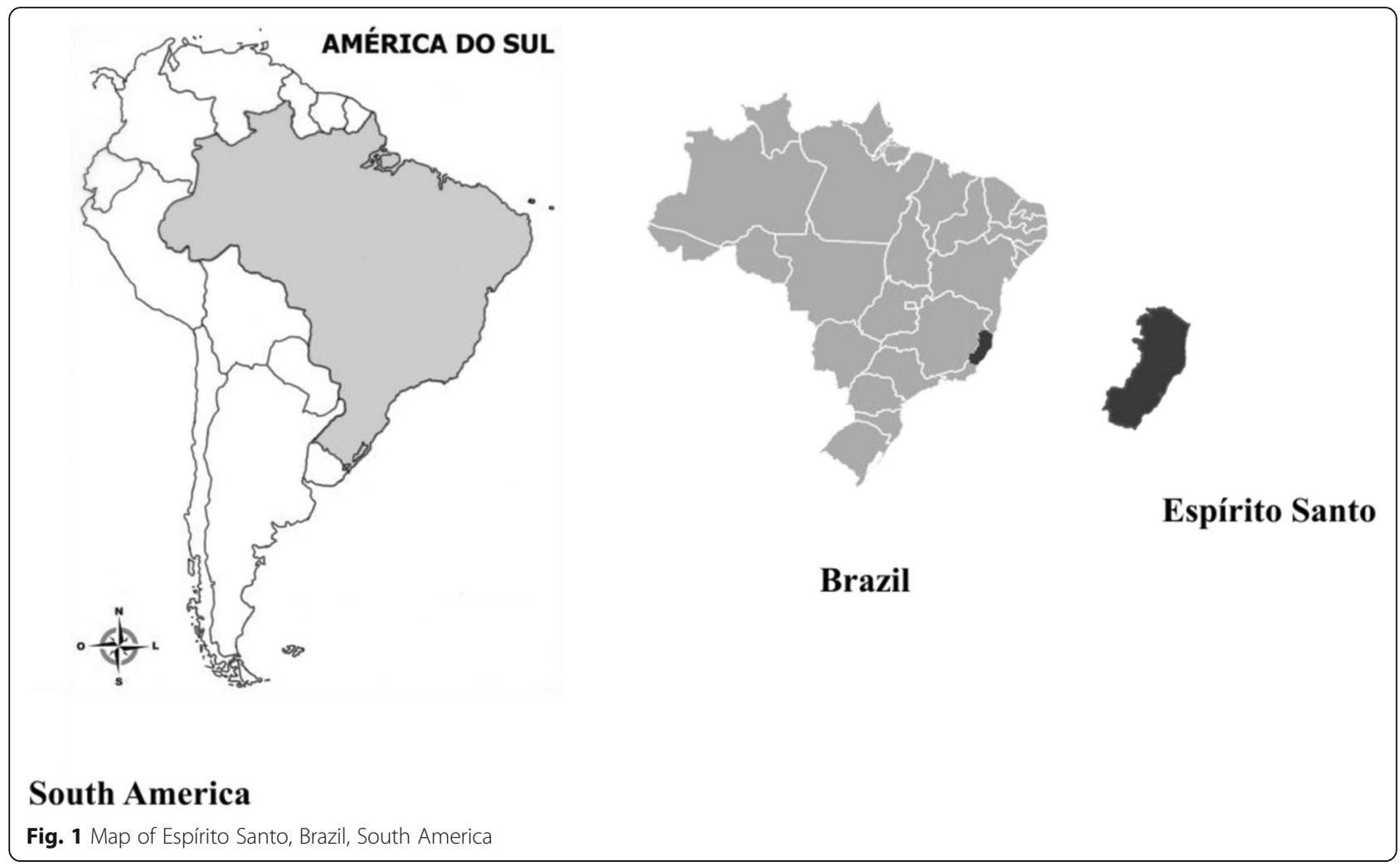

data is secondary and was obtained through medical reports, there was no parent's consent form used for the patients under 16 years old. There was no identification of the study's subjects, preserving the confidentiality and privacy of the study's candidates, and were approved by the Ethics and Research Committee of the Nossa Senhora da Gloria Children's Hospital (CAAE 19602813.8.0000.5069) after obtaining authorization from the State Office for Pharmaceutical Assistance.

\section{Study location}

The study was conducted in the Citizen's State Pharmacy sector of the Espírito Santo Office for Pharmaceutical Assistance, which is responsible for dispensing medications for patients with IBD in all State.

\section{Sample analyzed}

The sample included 1484 patients, with confirmed diagnosis, of all ages with IBD in the state of Espírito Santo (Fig. 1) who received medications through the

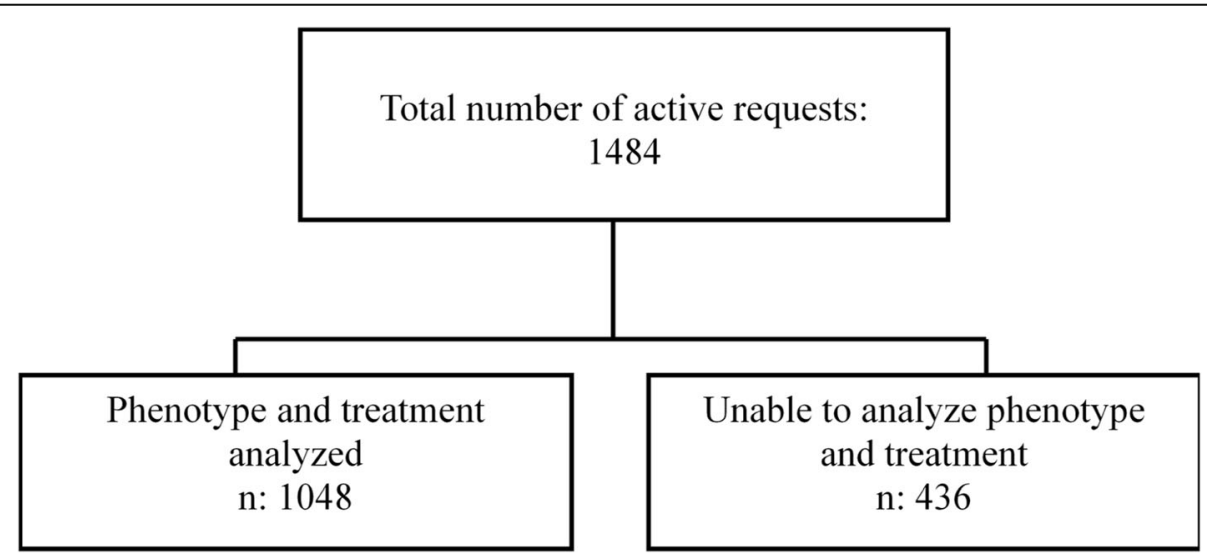

Fig. 2 Flowchart for the analysis of medication dispensing requests for IBD in Espírito Santo, Brazil 
Federal Government between August 1, 2012 and July 31, 2014 and for whom the incidence and prevalence of IBD was determined. Phenotype and treatment information was not available for 436 patients, and therefore data for 1048 patients were used (Fig. 2).

\section{Study design}

In medication-dispensing services the evaluation is conducted by only one gastroenterologist physician, in this case, the main author, who was responsible for dispensing the medication for IBD, and data analyzed were obtained through the analysis of administrative requests of these medications, and included medical report, endoscopy exams, histopathology and imaging tests, which followed the Clinical Protocols and Therapeutic Guidelines of the Brazilian Government $[13,14]$. The diagnosis of IBD and the phenotype were established according to the Montreal criteria [17] for Crohn's disease (CD), ulcerative colitis (UC). The patients whose endoscopic examination, image and histopathological examination, laboratorial, associated to medical reports describing the difficulty to define $\mathrm{CD}$ and $\mathrm{UC}$ the terminology unclassified inflammatory bowel disease (UIBD) was applied.

Dependent variables included the diagnosis, IBD classification, new cases (patients who received the diagnosis within one year of starting the administrative request), chronic cases (patients who received the diagnosis more than one year from starting the administrative request), and medications. Independent variables included age and gender.

Table 1 Distribution of ulcerative colitis and Crohn's disease

\begin{tabular}{|c|c|c|c|c|c|c|}
\hline \multicolumn{2}{|l|}{ Demographic variables } & \multicolumn{5}{|c|}{$\frac{\mathrm{IBD}}{n=1026}$} \\
\hline & & \multicolumn{2}{|c|}{$\overline{U C}$} & \multicolumn{2}{|l|}{$C D$} & \multirow[t]{2}{*}{$p$} \\
\hline & & $n$ & $\%$ & $n$ & $\%$ & \\
\hline \multirow[t]{2}{*}{ Year (Yr) } & 2013 & 339 & $62.8 \%$ & 207 & $37.92 \%$ & 0.043 \\
\hline & 2014 & 330 & $68.75 \%$ & 150 & $31.25 \%$ & \\
\hline \multirow[t]{3}{*}{ Age at diagnosis $(A)^{a}$} & $A 1: \leq 16$ & 23 & $3.40 \%$ & 25 & $7.00 \%$ & \\
\hline & A2: $17-40$ & 318 & $47.50 \%$ & 208 & $58.30 \%$ & 0.001 \\
\hline & $\mathrm{A} 3:>40$ & 328 & $49.00 \%$ & 124 & $34.70 \%$ & \\
\hline \multirow[t]{2}{*}{ Gender } & Female & 407 & $60.80 \%$ & 195 & $54.60 \%$ & 0.156 \\
\hline & Male & 262 & $39.20 \%$ & 162 & $45.40 \%$ & \\
\hline \multirow[t]{2}{*}{ New cases } & 2013 & 215 & $51.3 \%$ & 117 & $55.7 \%$ & 0.346 \\
\hline & 2014 & 204 & $48.7 \%$ & 94 & $44.3 \%$ & \\
\hline \multirow[t]{2}{*}{ Old Cases } & 2013 & 124 & $49.6 \%$ & 90 & $61.6 \%$ & 0.058 \\
\hline & 2014 & 126 & $50.4 \%$ & 56 & $38.4 \%$ & \\
\hline
\end{tabular}

${ }^{a}$ Age at diagnosis is not a phenotypic element of the Montreal classification for ulcerative colitis; UC ulcerative colitis, $C D$, Crohn's disease

\section{Study limitations}

The study was conducted with secondary data and some information has been compromised, such as in some cases the endoscopic report was not included and only the histopathology report was analyzed. Not all $C D$ patients included in the study had an upper gastrointestinal endoscopy/biopsy, and magnetic resonance and some older documents have been damaged due to time, making it impossible to define the localization of the disease in some cases.

In Brazil, medications for IBD are expensive and provided by the Public Health System for patients treated in the public and private systems. However, it is possible that some patients in the private system obtain their medications directly from drugstores without utilizing the public system.

\section{Statistical analysis}

An Excel spreadsheet was used to collect the data, and the data were analyzed using SPSS Statistics 20.0 software. Data were tabulated and analyzed through descriptive analysis of frequencies, percentages, averages, and standard deviations (SD). To determine associations between categorical variables, achi-square test was used, and Fisher's exact test was also used when appropriate. Student's t-test or ANOVA were used for quantitative variables. A $p$ value of $<0.05$ was considered statistically significant.

Data from the Brazilian Institute of Geography and Statistics was used to calculate prevalence and incidence based on the last census in 2014, in which the population of Espírito Santo was 3,885,049 [16]. To calculate prevalence, the total number of active requests at the Citizen's State Pharmacy (1484) was used. To calculate incidence, new cases arising in the second year of the study were used (August 1, 2013 to July 31, 2014).

\section{Results}

There were 1484 registered patients who received medication in the state of Espírito Santo. Considering the population in the region in 2014, the prevalence of IBD in the state was $38.2 / 10^{5}$ inhabitants. From these, 935 (63\%) were diagnosed with UC and 549 (37\%) were diagnosed with $\mathrm{CD}$, yielding prevalence of 24.1 per 100,000 and 14.1 per 100,000 inhabitants, respectively. The incidence was calculated based on new cases in 2014 (298 patients - 204 UC and 94 $\mathrm{CD}$ ), with an incidence of IBD of 7.7/100,00 inhabitants/year (UC 5.3/100,000 inhabitants/year and CD 2.4/100,000 inhabitants/year).

1Demographic data are summarized in Table 1 and refer to the 1048 patients whose administrative requests were reviewed, of whom 669 (63.84\%) had a 
Table 2 Clinical characteristics of ulcerative colitis $(n=654)$

\begin{tabular}{|c|c|c|c|c|c|c|c|c|}
\hline \multirow[t]{4}{*}{ Phenotypic elements } & & \multicolumn{7}{|c|}{ Extension } \\
\hline & & \multicolumn{2}{|c|}{ E1 } & \multicolumn{2}{|l|}{ E2 } & \multicolumn{2}{|l|}{ E3 } & \multirow[t]{3}{*}{$p$} \\
\hline & & \multicolumn{2}{|c|}{ Proctitis } & \multicolumn{2}{|c|}{ Left-sided colitis } & \multicolumn{2}{|c|}{ Pancolitis } & \\
\hline & & $\mathrm{n}$ & $\%$ & $n$ & $\%$ & $n$ & $\%$ & \\
\hline \multirow[t]{3}{*}{ Age at diagnosis $(A)^{a}$} & $\mathrm{~A} 1: \leq 16$ & 3 & 13.0 & 6 & 26.1 & 14 & 60.9 & \multirow[t]{3}{*}{0.007} \\
\hline & A2: $17-40$ & 89 & 28.4 & 116 & 37.1 & 108 & 34.5 & \\
\hline & A3: $>40$ & 106 & 30.5 & 125 & 39.3 & 87 & 26.8 & \\
\hline \multirow[t]{2}{*}{ Gender } & Female & 126 & 31.5 & 153 & 38.2 & 121 & 30.2 & \multirow[t]{2}{*}{0.469} \\
\hline & Male & 72 & 28.3 & 94 & 37.0 & 88 & 32.0 & \\
\hline
\end{tabular}

${ }^{\mathrm{a} A g e}$ at diagnosis is not a phenotypic element of the Montreal classification for ulcerative colitis

diagnosis of UC, 357 (34.06\%) had a diagnosis of CD, and $22(2.10 \%)$ had a diagnosis of UIBD.

The disease phenotype could not be determined for all patients due to a lack of information in the administrative requests. The phenotypes evaluated are available in Tables 2, 3 and 4. For pediatric patients (16 years of age or younger), 48/1048 (4.5\%) patients had IBD, among whom 23/48 (48\%) had UC and 25/48 (52\%) had CD in Table 1. Pancolitis was more frequent in pediatric patients $(p=0.007)$, available in Table 2 . In Crohn's disease the inflammatory and perianal fistulizing behavior were more frequent, Table 4 .

Medication dispensing for patients with IBD is shown in Fig. 3. For UC patients, 591/654 (90,3\%) treated with oral aminosalicylates, 438 (74\%) have left-sided colitis or pancolitis and those treated with azathioprine, 110/ $127(86,8 \%)$ had left-sided colitis and pancolitis. The biological treatment was prescribed for $30(4,5 \%)$ patients with UC, with pancolitis $21(70 \%)$ and left-sided colitis 9 (30\%). For CD patients, treatment with the immunomodulator was prescribed in 253/357 (70,9\%), and in $153 / 357(43,4 \%)$ of the cases the biological therapy was used, due to perianal involvement $71 / 152$ $(46,7 \%)$.

\section{Discussion}

In Brazil the prevalence of IBD in the state of Espírito Santo $(38,2 / 100.000$ inhabitants), was higher. Parente et al. in Piauí, Brazil, in 2015 [11] analyzing a University Hospital in the northeast region of Brazil found a prevalence of 12.8 cases/100,000 inhabitants and Victoria et al. in São Paulo, Brazil, between 2001 and 2005 [9], analyzing a University Hospital in the southeast region of Brazil found a prevalence of 22.6 cases/ 100,000 inhabitants, which only analyzed reference points (University Hospitals). The prevalence of IBD in the state of Espírito Santo, Brazil, was higher (38.2/ $10^{5}$ inhabitants) because we had data from patients from the whole State, which included the public and private healthcare system. The incidence of IBD in Espírito Santo was also higher than the incidence found by Parente et al. in 2015 [11], when the institution's incidence peaked at 1.53 cases/100,000 in 2007, which is similar to the data from Porto Rico in 2005 $[10,18]$. The incidence of UC was closer to the values found by Victoria et al. in São Paulo [9] and equivalent to those in Porto Rico (Central America) $[10,18]$ but higher than those in other countries in Central and South America [10].

The evaluation of frequency distributions of IBD showed a predominance of UC, similar to the study published by Burisch et al. in 2014 [19], which compared Eastern and Western Europe and observed a predominance of $\mathrm{UC}$ in both regions. The same is observed for Brazilian studies $[9,11,20]$. The frequency distribution between the two forms of IBD shows geographic variations, with a higher predominance of UC in Nordic countries [8]. There is a tendency for $\mathrm{CD}$ to predominate in developed countries such as Canada and the USA [8]. In some

Table 3 Clinical characteristics of Crohn's disease $(n=357)$

\begin{tabular}{|c|c|c|c|}
\hline \multicolumn{2}{|c|}{ Phenotypic elements } & \multicolumn{2}{|c|}{ Total DC } \\
\hline & & $n$ & $\%$ \\
\hline \multirow{6}{*}{$\begin{array}{l}\text { Location (L) } \\
(n=353)\end{array}$} & L1: terminal ileum & 111 & 31.4 \\
\hline & L2: colonic & 102 & 28.9 \\
\hline & L3: ileocolonic & 109 & 30.9 \\
\hline & L4: isolated upper disease & 11 & 3.2 \\
\hline & $L 1+L 4$ & 8 & 2.3 \\
\hline & $\mathrm{L} 3+\mathrm{L} 4$ & 12 & 3.4 \\
\hline \multirow{6}{*}{$\begin{array}{l}\text { Behavior (B) } \\
(n=352)\end{array}$} & B1: nonstricturing/non-fistulizing & 176 & 50.0 \\
\hline & B2: stricturing & 56 & 15.9 \\
\hline & B3: fistulizing & 29 & 8.2 \\
\hline & $\mathrm{B} 1 \mathrm{p}^{\mathrm{a}}$ & 27 & 7.7 \\
\hline & B2 $p^{a}$ & 18 & 5.1 \\
\hline & B3p $p^{a}$ & 46 & 13.1 \\
\hline \multirow[t]{2}{*}{ Gender } & Female & 195 & 54.6 \\
\hline & Male & 162 & 45.4 \\
\hline
\end{tabular}

${ }^{a} p$ perianal disease modifier 
Table 4 Crohn disease 's behavior in relation to age and gender

\begin{tabular}{|c|c|c|c|c|c|c|c|c|c|c|c|c|c|c|}
\hline \multirow[t]{3}{*}{ Phenotypic elements } & & \multicolumn{13}{|c|}{ Behavior (B) } \\
\hline & & \multicolumn{2}{|l|}{$\overline{B 1}$} & \multicolumn{2}{|l|}{ B2 } & \multicolumn{2}{|l|}{ B3 } & \multicolumn{2}{|c|}{ B1p } & \multicolumn{2}{|c|}{ B2p } & \multicolumn{2}{|c|}{ B3p } & \multirow[t]{2}{*}{$p$} \\
\hline & & $\mathrm{n}$ & $\%$ & $n$ & $\%$ & $n$ & $\%$ & $n$ & $\%$ & $n$ & $\%$ & $n$ & $\%$ & \\
\hline \multirow[t]{3}{*}{ Age at diagnosis (A) } & $\mathrm{A} 1: \leq 16$ & 10 & 5.6 & 0 & 0.0 & 2 & 6.9 & 3 & 11.1 & 1 & 5.6 & 9 & 19.6 & \multirow[t]{3}{*}{0.001} \\
\hline & A2: $17-40$ & 90 & 50.9 & 30 & 53.6 & 20 & 69.0 & 20 & 74.1 & 16 & 88.8 & 29 & 63.0 & \\
\hline & $\mathrm{A} 3:>40$ & 77 & 43.5 & 26 & 46.4 & 7 & 24.1 & 4 & 14.8 & 1 & 5.6 & 8 & 17.4 & \\
\hline \multirow[t]{2}{*}{ Gender } & Female & 110 & 62.1 & 26 & 46.4 & 16 & 55.2 & 10 & 37.0 & 11 & 61.1 & 22 & 47.8 & \multirow[t]{2}{*}{0.042} \\
\hline & Male & 67 & 37.9 & 30 & 53.6 & 13 & 44.8 & 17 & 63.0 & 7 & 38.9 & 24 & 52.2 & \\
\hline
\end{tabular}

B1 nonstricturing/non-fistulizing, $B 2$ stricturing, $B 3$ fistulizing, p-perianal disease modifier

countries in Eastern Europe, there is an equal frequency of both forms of IBD [8].

For pediatric patients (16 years of age or younger), $48 / 1048$ (4.5\%) patients had IBD, among whom 23/48 (48\%) had UC and 25/48 (52\%) had CD. These frequencies are lower than the overall means of 10 to $25 \%$ of pediatric patients with UC and CD, respectively, reported in the literature [21, 22]. However, the frequency was similar to that observed in a study performed in Western and Eastern Europe [19], in which $45 / 1560(3 \%)$ of patients with IBD were younger than 15 years of age.

Evaluation of UC phenotype showed that left-sided colitis was more frequent, followed by pancolitis and proctitis, which occurred with relatively similar frequency. These results were similar to those found in a comparative study between Western and Eastern Europe [19], which observed left-sided colitis (E2) in 41 and $46 \%$ of patients, followed by pancolitis (E3) in 38 and $32 \%$ of patients, and proctitis (E1) in 20 and $22 \%$ of individuals from Western and Eastern Europe, respectively. These were also similar to the results of a Brazilian study by Parente et al. from 2015 [11]. The distribution and location of CD is relatively homogeneous and stable during its progression [23, 24]. In the current study, there was equivalence between the ileal (L1), colonic (L2), and ileocolonic (L3) forms, which is in agreement with data from some studies $[2,17,24]$ but differs from the results of Brazilian studies [11, 20]. Regarding the involvement of the upper gastrointestinal tract (UGI) in isolation or in association with other locations, we observed a frequency of $8.8 \%(31 / 353)$, which is similar to the values of 10 to $15 \%$ previously reported in the literature [24].

In the current study, we observed that the inflammatory behavior was in agreement with data from the literature [11, 19, 25]. Perianal involvement was more frequent in younger patients, which characterizes a more severe presentation of the disease in this group of patients. Similar results were observed by Parente et al. [11] and in the European study by Burisch et al. in 2013 [2]. The fistulizing form occurred in $21.2 \%$ of patients, whereas it was isolated (B3) in $8.2 \%$ of patients and associated with perianal involvement (B3p) in $13.1 \%$ of patients. Our data are similar to data from Asia (19\%) [3] and the study by Parente et al. [11], which found the B3 form in 13\% of patients and the B3p form in 5\% of patients.

Regarding the distribution of medications, we observed the use of biologic therapies in $43.3 \%$ of patients with $C D$, which suggests the occurrence of more severe

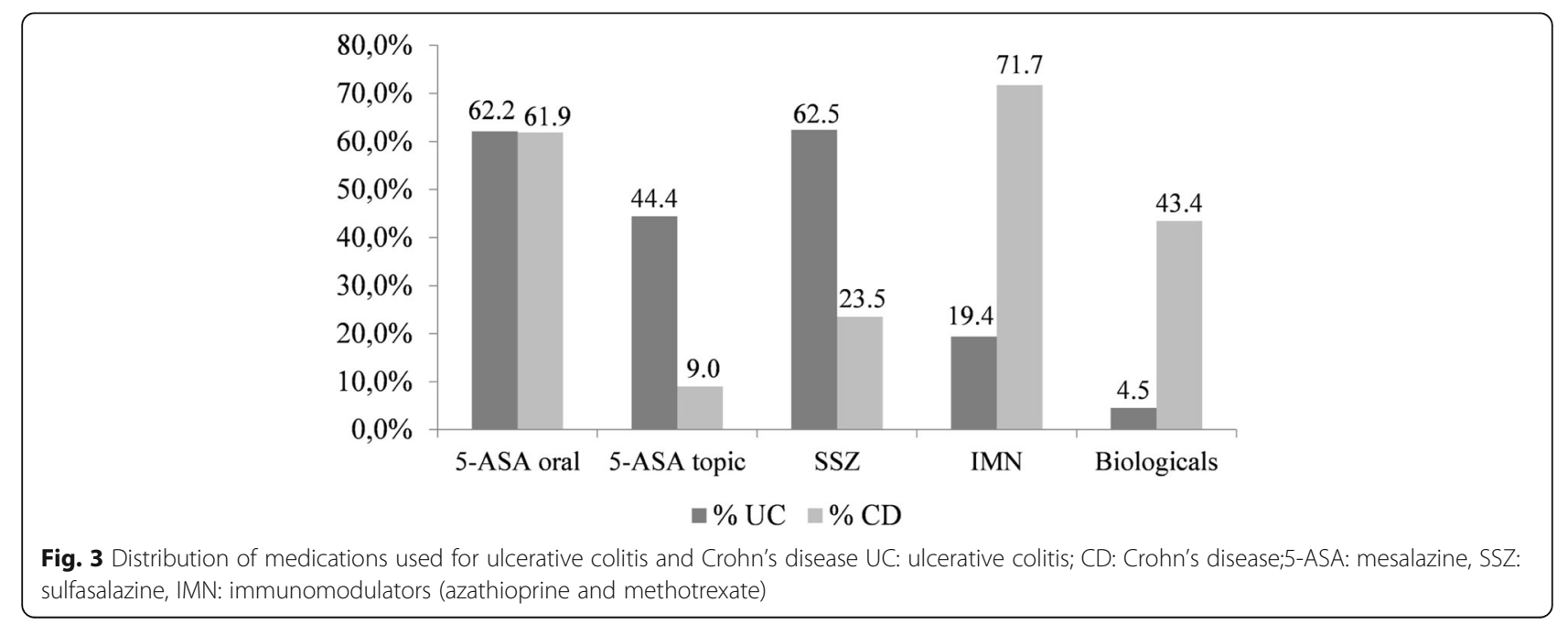


CD; however, more studies are needed to assess the association between treatment and phenotype. Regarding the use of systemic aminosalicylates, we observed a higher frequency in patients with $C D$, which is not in accordance with current management guidelines, in which they are indicated for mild forms of the disease located in the ileum and for colonic forms of $\mathrm{CD}$, for which there is evidence of efficacy [14, 26-29].

\section{Conclusion}

The present study found a tendency for higher prevalence and incidence of IBD in Brazil, with values approaching those of regions with moderate incidence and prevalence $[4,8]$. Our region is comprised of European immigrants, with one of the largest populations of Italians in Brazil [15, 30], which could justify the data found in our study. However, to date, there have been no studies to assess factors related to etiopathogenesis. Regarding the distribution of demographic and phenotypic data, there were no large differences compared to studies from other regions. Understanding of the epidemiology and phenotypic characteristics can contribute to a better organization and political-economic planning of public health.

\section{Abbreviations}

5-ASA: Mesalazine; CAAE: Certificate of Presentation for Ethical Consideration; CD: Crohn's disease; IBD: Inflammatory bowel disease;

IMN: Immunomodulators; SSZ: Sulfasalazine; UC: Ulcerative colitis;

UIBD: Unclassified inflammatory bowel disease

\section{Acknowledgements}

The authors are grateful for the support provided by the team at Citizen's State Pharmacy, especially Maria Jose Sartório (Manager of State Office for Pharmaceutical Assistance)

\section{Author contributions}

AM: concept and designed the research and collected the data. MPG: designed the research. AM, MPG and RV: contributed to data analyses and interpretation. AM and MPG: wrote the manuscript. All the authors have read and approved the final manuscript.

\section{Availability of data and materials}

The datasets generated and/or analysed during the current study are not publicly available due to the fact that they are part of a research with additional data that will be published in the future but are available from the corresponding author on reasonable request.

\section{Ethics approval and consent to participate}

This study was approved by the Ethics and Research Committee of the Nossa Senhora da Gloria Children's Hospital (CAAE 19602813.8.0000.5069) after obtaining authorization from the State Office for Pharmaceutical Assistance.

\section{Consent for publication}

Not applicable.

\section{Competing interests}

The authors declare that they have no competing interests.

\section{Publisher's Note}

Springer Nature remains neutral with regard to jurisdictional claims in published maps and institutional affiliations.

\section{Author details}

State Management of Pharmaceutical Assistance and Ambulatory of Inflammatory Bowel Disease of the Health Department of Espírito Santo, Núcleo Regional de Especialidades de Vitória, BR 262, Km 0, Ed. Eng. Cristiano Tavares, $2^{\circ}$ andar, Jardim América, Cariacica, Espírito Santo 29140-126, Brazil. ${ }^{2}$ Laboratory of Estatistic-Departament of de Federal University of Espírito Santo, Av. Fernando Ferrari s/n, Goiabeiras, Vitória, Espírito Santo 29060-900, Brazil. ${ }^{3}$ Departament of Medicine, Federal University and University Hospital Cassiano Antonio Moraes of Espírito Santo, Av. Marechal Campos, 1468, Vitória, ES 29042-755, Brazil. ${ }^{4}$ Desembargador Ferreira Coelho 330/315 Praia do Suá, Ed. Eldorado, Vitoria 29052210, Brazil.

Received: 4 April 2017 Accepted: 11 June 2018

Published online: 18 June 2018

\section{References}

1. Burisch J. Crohn's disease and ulcerative colitis. Occurrence, course and prognosis during the first year of disease in a European population-based inception cohort. Dan Med J. 2014;61:B4778

2. Burisch J, Jess T, Martinato M, et al. ECCO-EpiCom. The burden of inflammatory bowel disease in Europe. J Crohns Colitis. 2013;7:322-37.

3. Ng SC, Tang W, Ching JY, et al. Asia-Pacific Crohn's and Colitis Epidemiologic Study (ACCESS) Study Group. Incidence and phenotype of inflammatory bowel disease based on results from the Asia-pacific Crohn's and colitis epidemiology study. Gastroenterology. 2013;145:158-65.

4. Molodecky NA, Soon IS, Rabi DM, et al. Increasing incidence and prevalence of the inflammatory bowel diseases with time, based on systematic review. Gastroenterology. 2012;142:46-54.

5. Loftus EV Jr, Schoenfeld P, Sandborn WJ. The epidemiology and natural history of Crohn's disease in population-based patient cohorts from North America: a systematic review. Aliment Pharmacol Ther. 2002;16:51-60.

6. Baumgart DC, Bernstein CN, Abbas Z, et al. IBD around the world: comparing the epidemiology, diagnosis, and treatment: proceedings of the world digestive health day 2010-inflammatory bowel disease task force meeting. Inflamm Bowel Dis. 2011;17:639-44.

7. Burisch J, Munkholm P. The epidemiology of inflammatory bowel disease. Scand J Gastroenterol. 2015;50:942-51.

8. $\mathrm{Ng} \mathrm{SC}$, Bernstein CN, Vatn MH, et al. Epidemiology and natural history task force of the International Organization of Inflammatory Bowel Disease (IOIBD). Geographical variability and environmental risk factors in inflammatory bowel disease. Gut. 2013:62:630-49.

9. Victoria $C R$, Sassak LY, Nunes HR. Incidence and prevalence rates of inflammatory bowel diseases, in midwestern of São Paulo state, Brazil. Arq Gastroenterol. 2009;46:20-5.

10. Farrukh A, Mayberry JF. Inflammatory bowel disease in Hispanic communities: a concerted south American approach could identify the etiology of Crohn's disease and ulcerative colitis. Arq Gastroenterol. 2014:51:271-5.

11. Parente JM, Coy CS, Campelo V, et al. Inflammatory bowel disease in an underdeveloped region of northeastern Brazil. World J Gastroenterol. 2015; 21:1197-206.

12. Secretaria de Saúde do Estado do Espírito Santo. Assistência FarmacêuticaFarmácia Cidadã. https://farmaciacidada.es.gov.br/farmacia-cidada-estadual. Acessed 3 Jan 2015

13. Ministério da Saúde(BR). Secretaria de Atenção à Saúde. Portaria SAS/MS nº 2.981, de 04 de novembro de 2002, Protocolo Clínico e Diretrizes Terapêuticas da Retocolite Ulcerativa. http://portalsaude.saude.gov.br/ images/pdf/2014/abril/02/pcdt-retocolite-ulcerativa-livro-2002.pdf Accessed 3 Jan 2015.

14. Ministério da Saúde (BR). Secretaria de Atenção à Saúde. Portaria SAS/MS no 711, de 17 de dezembro de 2010. Protocolo Clínico e Diretrizes Terapêuticas da Doença de Crohn. http://portalarquivos.saude.gov.br/ images/pdf/2015/abril/17/Minuta-de-Portaria-SAS-PCDT-Doen-a-de-Crohn30-09-2014-RETIFICADO.pdf. Acessed 3 Jan 2015.

15. Instituto Brasileiro de Geografia e Estatística (IBGE). http://brasil500anos.ibge. gov.br/territorio-brasileiro-e-povoamento/italianos/regioes-de-destino.html. Accessed 3 Aug 2015

16. Instituo Brasileiro de Geografia e Estatística (IBGE). Censo 2014. ftp://ftp.ibge. gov.br/Estimativas_de_Populacao/Estimativas_2014/estimativa_TCU_2014_ 20170614.pdf. Accessed 3 Aug 2015. 
17. Silverberg MS, Satsangi J, Ahmad T, et al. Toward an integrated clinical, molecular and serological classification of inflammatory bowel disease: report of a working party of the 2005 Montreal world congress of gastroenterology. Can J Gastroenterol. 2005;19(Suppl A):5A-36A.

18. Appleyard CB, Hernández G, Rios-Bedoya CF. Basic epidemiology of inflammatory bowel disease in Puerto Rico. Inflamm Bowel Dis. 2004;10: 106-11.

19. Burisch J, Pedersen N, Čuković-Čavka S, et al. East-west gradient in the incidence of inflammatory bowel disease in Europe: the ECCO-EpiCom inception cohort. Gut. 2014;63:588-97.

20. Kleinubing-Júnior H, Ferreira LC, Pinho MSL, et al. Perfil dos pacientes ambulatoriais com doenças inflamatórias intestinais/Outpatients profile with inflammatory bowel disease. ABCD Arq Bras Cir Dig. 2011;24:200-3.

21. Benchimol El, Fortinsky KJ, Gozdyra P, et al. Epidemiology of pediatric inflammatory bowel disease: a systematic review of international trends. Inflamm Bowel Dis. 2011;17:423-39.

22. Cuffari C. Inflammatory bowel disease in children: a pediatrician's perspective. Minerva Pediatr. 2006;58:139-57.

23. Van Assche G, Dignass A, Panes J, et al. European Crohn's and colitis organization (ECCO). The second European evidence-based consensus on the diagnosis and management of Crohn's disease: definitions and diagnosis. J Crohns Colitis. 2010:4:7-27.

24. Cosnes J, Gower-Rousseau C, Seksik P, et al. Epidemiology and natural history of inflammatory bowel diseases. Gastroenterology. 2011;140: 1785-94.

25. Park SJ, Kim WH, Cheon JH. Clinical characteristics and treatment of inflammatory bowel disease: a comparison of eastern and western perspectives. World J Gastroenterol. 2014;20:11525-37.

26. Mowat C, Cole A, Windsor A, et al. IBD section of the British Society of Gastroenterology. Guidelines for the management of inflammatory bowel disease in adults. Gut. 2011;60:571-607.

27. Dignass A, Van Assche G, Lindsay JO, et al. European Crohn's and Colitis Organization (ECCO). The second European evidence-based Consensus on the diagnosis and management of Crohn's disease: Current management. J Crohns Colitis. 2010;4:28-62. Erratum in: J Crohns Colitis 2010; 4: 353. Dosage error in article Text.

28. Terdiman JP, Gruss CB, Heidelbaugh JJ, et al. AGA Institute clinical practice and quality management committee. American Gastroenterological Association Institute guideline on the use of thiopurines, methotrexate, and anti-TNF-a biologic drugs for the induction and maintenance of remission in inflammatory Crohn's disease. Gastroenterology. 2013;145:1459-63.

29. Bernstein CN. Treatment of IBD: where we are and where we are going. Am J Gastroenterol. 2015:110:114-26.

30. Brasil Escola. "Aspectos da população do Espírito Santo". http://brasilescola. uol.com.br/brasil/aspectos-populacao-espirito-santo.htm Accessed 3 Aug 2015

\section{Ready to submit your research? Choose BMC and benefit from:}

- fast, convenient online submission

- thorough peer review by experienced researchers in your field

- rapid publication on acceptance

- support for research data, including large and complex data types

- gold Open Access which fosters wider collaboration and increased citations - maximum visibility for your research: over $100 \mathrm{M}$ website views per year

At BMC, research is always in progress.

Learn more biomedcentral.com/submissions 